\title{
THE USE OF THE PETRI NET METHOD IN THE SIMULATION MODELING OF MITOCHONDRIAL SWELLING
}

\author{
Yu. V. DANYLOVYCH, A. Y. CHUNIKHIN, \\ G. V. DANYLOVYCH, O. V. KOLOMIETS \\ Palladin Institute of Biochemistry, National Academy \\ of Sciences of Ukraine, Kyiv; \\ e-mail: danylovych@biochem.kiev.ua
}

\begin{abstract}
Using photon correlation spectroscopy, which allows investigating changes in the hydrodynamic diameter of the particles in suspension, it was shown that ultrahigh concentrations of $\mathrm{Ca}^{2+}$ (over $10 \mathrm{mM}$ ) induce swelling of isolated mitochondria. An increase in hydrodynamic diameter was caused by an increase of nonspecific mitochondrial membrane permeability to Ca ions, matrix $\mathrm{Ca}^{2+}$ overload, activation of ATP-and $\mathrm{Ca}^{2+}$-sensitive $\mathrm{K}^{+}$-channels, as well as activation of cyclosporine-sensitive permeability transition pore. To formalize the experimental data and to assess conformity of experimental results with theoretical predictions we developed a simulation model using the hybrid functional Petri net method.
\end{abstract}

Key words: mitochondria, Petri nets, calcium, permeability transition pore, photon correlation spectroscopy.

$\mathrm{R}$ egulation of matrix volume is important for the mitochondria functioning and maintaining of their integrity. The mitochondrial volume affects the respiration rate and the level of ATP production. There is a correlation between changes in the geometry of these organelles and such events as the generation of reactive oxygen species, the polarization of the inner mitochondrial membrane, the ability to apoptosis. Mitochondrial swelling is not only the final stage of their dysfunction, but also a key feature in the biochemical mechanisms of cell damage. It leads to the straightening of the cristae, disruption of the outer membrane integrity and release of apoptogenic factors such as cytochrome $\mathrm{c}$ and apoptosis-inducing factor, etc. into cytosol [1-4].

In vitro experiments on isolated mitochondria suspension standard approaches such as: inner mitochondria membrane permeabilization by antibiotics, matrix $\mathrm{Ca}^{2+}$ loading in the presence of $\mathrm{Ca}^{2+}$ ionophore A-23187, induction of the non-specific membrane permeability by $\mathrm{Ca}$ ions and long chain saturated fatty acids, etc., to initiate swelling of the organelles are often used $[5,6]$. In this work we propose another model approach for the initiation of increasing of non-specific permeability of the inner mitochondrial membrane and the matrix volume, namely the use of calcium ions in the ultrahigh (tens of $\mathrm{mM}$ ) concentrations. In our view, this model for swelling of isolated mitochondria in vitro is less invasive and destructive. In particular, it does not apply the perforation of the inner membrane and a substantial chemical modification of the lipid bilayer.

To formalize and generalize the experimental data, to reduce the number of measurements and replace them with mathematical calculations, and also to assess conformity of experimental results with theoretical predictions we developed a simulation model, which connects the changes in mitochondria hydrodynamic diameter under effect of $\mathrm{Ca}^{2+}$ and a conception of their structural and functional features. As an approach for modeling of changes in mitochondria volumetric characteristics under the influence of $\mathrm{Ca}$ ions, ATP, cyclosporine, $\mathrm{K}^{+}$-channel inhibitors, nitrocompounds, etc., we proposed to use hybrid functional Petri nets [7, 8].

The advantages of the hybrid functional Petri nets as a modeling method are [9]:

1. Capability to structurally represent the states of the modeled system and the processes occurring in the system.

2. Quantitative modeling of three types of states and processes simultaneously: discrete, continuous and associative (forming).

3. Possibility to consider the activating, inhibiting and catalytic effects by the means of a special type of bonds.

The process of swelling is commonly evaluated on the changes in optical density/light scattering of the mitochondrial suspension. The photon correla- 
tion spectroscopy technique is informative and efficient for analysis of the size of spherical-like particles in the solutions. This method is highly sensitive (the changes in volume from $0.1 \%$ can be registered and the particles with diameter from 0.001 to $20 \mu \mathrm{m}$ can be analyzed); it requires a minor amount of experimental material, and also allows eliminating the artifacts associated with small size of subcellular particles, which occur at application of other optical approaches. Photon correlation spectroscopy provides direct determination of the hydrodynamic diameter of isolated myometrium mitochondria (effective size) in experimental conditions [7, 10, 11].

Thus, the aim of the present work was to develop a simulation model for swelling of isolated myometrium mitochondria in hypercalcium solution using Petri nets methodology and perform inhibitory analysis of this process using photon correlation spectroscopy.

\section{Materials and Methods}

The preparation of isolated mitochondria was obtained from non-pregnant rat myometrium using differential centrifugation as described previously with minor modifications [12]. After uterus removal and its purification from adipose and connective tissue the preparation was kept in $0.9 \% \mathrm{NaCl}$ solution. Myometrium was cut with scissors into pieces (roughly $2 \times 2 \mathrm{~mm}$ ), which were put into the working solution with the following composition: $10 \mathrm{mM}$ Hepes (pH 7.4), $250 \mathrm{mM}$ sucrose, $1 \mathrm{mM}$ EGTA at $4{ }^{\circ} \mathrm{C}$. Tissue was homogenized with a homogenizer Polytron thrice for $20 \mathrm{~s}$ each time with cooling on ice for $1 \mathrm{~min}$. The tissue:working solution ratio was $1: 10$. Homogenate was centrifuged at $1000 \mathrm{~g}$ for $15 \mathrm{~min}$ at $4{ }^{\circ} \mathrm{C}$. Supernatant was centrifuged at $12000 \mathrm{~g}$ for $15 \mathrm{~min}$ at $4{ }^{\circ} \mathrm{C}$. The pellet was resuspended in the working solution and again centrifuged at $12000 \mathrm{~g}$ for $15 \mathrm{~min}$ at $4{ }^{\circ} \mathrm{C}$. The obtained isolated mitochondria were kept on ice during the experiment.

Protein concentration in the mitochondria fraction was determined by Bradford assay [13]. Its average value was $2 \mathrm{mg} / \mathrm{ml}$ and in the sample was $50 \mu \mathrm{g} / \mathrm{ml}$.

To assess changes in the mitochondria volume we used photon correlation spectroscopy method, which allows determining their characteristic sizes (average hydrodynamic diameter). Particle volume in suspension was analyzed using correlation spectrometer ZetaSizer-3 (Malvern Instruments, UK) equipped with He-Ne laser LGN-111 ( $\mathrm{P}=25 \mathrm{~mW}$, $\lambda=633 \mathrm{~nm}$ ). Its operation principle is based on the analysis of the correlation characteristics of the fluctuation intensity of dynamic light scattering while laser ray passes through a medium with mitochondria. The measurements of the correlation function of the light scattering intensity fluctuations and integral scattering intensity enable to determine the translational diffusion coefficient for the dispersed particles in liquids, and to assess the particle size distribution using the Stokes-Einstein equation. Translational diffusion coefficient $D$ is related to duration of the correlation $\tau_{\mathrm{c}}$ with the ratio: $\mathrm{Dq}^{2}=1 / \tau_{\mathrm{c}}$.

The wave vector of concentration fluctuations $q$ is described by the expression:

$$
q=\frac{4 \pi n}{\lambda_{0}} \sin \left(\frac{\theta}{2}\right)
$$

where: $n$ is the refractive index of the medium (liquid); $\lambda$ is the wavelength; $\theta$ is the scattering angle.

Using the Stokes-Einstein equation that connects a particle size, translational diffusion coefficient and viscosity of the liquid we can calculate a size (diameter) $\mathrm{d}(\mathrm{H})$ of spherical particles [7]:

$$
d(H)=\frac{k_{B} \cdot T}{3 \pi \eta D},
$$

where: $k_{B}$ is Boltzmann constant; $T$ is absolute temperature, ${ }^{\circ} \mathrm{K} ; \eta$ is the shear viscosity of medium in which the particles are suspended; $D$ is translational diffusion coefficient.

Recording and statistical processing of changes in the scattering intensity in the water $(n=1.33) \mathrm{mi}-$ tochondria suspension were performed for $10 \mathrm{~min}$ 10 times at $+22^{\circ} \mathrm{C}$, at scattering angle $90^{\circ}$. The obtained results were processed using the PCS-Size mode v1.61 software.

In the first series of the experiments autocorrelation function was recorded in the incubation medium that did not contain physiological concentrations of $\mathrm{K}^{+}$, but contained sucrose (mM): 20 Hepes ( $\mathrm{pH} 7.4,37^{\circ} \mathrm{C}$ ), 250 sucrose, 2 potassium-phosphate buffer ( $\mathrm{pH} 7.4,37^{\circ} \mathrm{C}$ ), 5 succinate (sucrose medium). In the second series we used a medium containing physiological concentrations of $\mathrm{K}^{+}$with the following

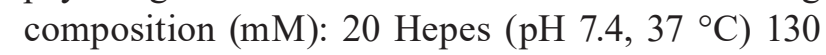
$\mathrm{KCl}, 2$ potassium-phosphate buffer $\left(\mathrm{pH} 7.4,37^{\circ} \mathrm{C}\right)$, 5 succinate (medium contains potassium chloride).

For modeling we chose Cell Illustrator v.3 software (Human Genome Center, University of Tokyo, 
Japan), the basic unit of which is a hybrid functional Petri nets [14]. Petri net is a directed bipartite graph with two types of nodes (Table 1): places and transitions, which are connected by arcs, reflecting the structure of the net. Places usually characterize objects, elements, resources of the modeled system, transitions - the events that occur in the system and logical conditions of their implementation.

\section{Results and Discussion}

It was found that the values of mitochondria hydrodynamic diameter ranged from 500 to $700 \mathrm{~nm}$ with a mean of $550 \pm 20 \mathrm{~nm}(n=5$, in experiments without cyclosporine) that corresponds well to the results of electron microscopy [11]. As an example we represented a typical case of function of mitochondria distribution in suspension in the presence of cyclosporin A, a compound that reduces the possible variation of size deviations from average values by blocking permeability transition pore (PTP) (Fig. 1). In the left part of the distribution function there are albumin, other globular proteins and lipoprotein complexes that are a minor part of the total number of objects.

We used $\mathrm{Ca}$ ions as agents that reliably trigger organelle swelling. The peculiarity of this research was registration of the effects of ultrahigh non-physiological concentrations of this cation: 10$25 \mathrm{mM}$. For comparison, the local $\mathrm{Ca}^{2+}$ concentration in the contact areas between the endoplasmic reticulum and mitochondria can reach more than $0.1 \mathrm{mM}$ [15]. However, we did not apply additional non-physiological agents, which artificially increase the nonspecific permeability of inner mitochondrial membrane. In the absence of $\mathrm{Ca}^{2+}$ in the medium we did not observe statistically significant increase in the volume of isolated organelles during $10 \mathrm{~min}$ in both working sucrose solution (Fig. 2) and in the presence of physiological concentrations of $\mathrm{K}^{+}$.

Swelling process induced by $20 \mathrm{mM} \mathrm{Ca}^{2+}$ reached the steady state within $10 \mathrm{~min}$. A substantial increase in mitochondrial volume was observed only in a medium containing $15-25 \mathrm{mM} \mathrm{Ca}^{2+}$ (Fig. 2, 3 ) in the absence of Mg-ATP ${ }^{2-}$ (obligatory condition). Increase in the hydrodynamic diameter appeared to be dependent on the $\mathrm{Ca}^{2+}$ concentration: the latter changes from 0 to $25 \mathrm{mM}$ followed by a significant increase in characteristic organelle sizes, and also the saturation on the cation concentration occurred. The barrier function of the inner mitochondrial membrane was so potent that even $10 \mathrm{mM} \mathrm{Ca}^{2+}$ did not cause a notable increase in the hydrodynamic diameter (Fig. 3).

Ruthenium red $(10 \mu \mathrm{M})$ is a dye that reacts with biomembrane mucopolysaccharides and sialic acids [16-18], and is considered as an inhibitor of $\mathrm{Ca}^{2+}$ transport of mitochondrial inner membrane $[15,19]$. It effectively inhibited the swelling in both mediums with sucrose and potassium chloride under action of $20 \mathrm{mM} \mathrm{Ca}^{2+}$ (Fig. 4).

Obviously, the increasing of hydrodynamic diameter is related not only to $\mathrm{Ca}^{2+}$ influx into mitochondria through the $\mathrm{Ca}^{2+}$-uniporter, since it is not only stimulated, but also effectively suppressed in the presence of $\mathrm{Mg}$-ATP ${ }^{2-}$-complex, which promotes the electrophoretic mitochondria $\mathrm{Ca}^{2+}$ accumulation (graph data are not shown). It is known that ruthenium red does not inhibit selectively enough $\mathrm{Ca}^{2+}$ uniporter, but also affects other mitochondrial $\mathrm{Ca}^{2+}$ transport system $[15,19]$ and even $\mathrm{Ca}^{2+}$-channels

Ta b le 1. The main structural elements of the hybrid functional Petri nets (see the text for the explanations)

\begin{tabular}{|c|c|c|c|c|}
\hline Type & Places & Transitions & Label & Arcs \\
\hline Discrete & $\begin{array}{c}\bigcup_{\text {integer }} \\
\text { Discrete place }\end{array}$ & $\begin{array}{c}\text { delay } \\
\text { Generic transition }\end{array}$ & Normal & threshold \\
\hline Continuous & $\begin{array}{l}\text { real number } \\
\text { Continuous place }\end{array}$ & $\square_{\text {rate }}$ & Test & 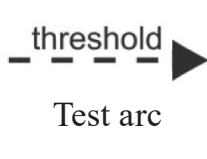 \\
\hline Generic & $\Theta_{\text {any types }}$ & $\begin{array}{c}\text { any operation } \\
\text { Generic transition }\end{array}$ & Inhibitory & $\begin{array}{l}\text { threshold } \\
\text { Inhibitory arc }\end{array}$ \\
\hline
\end{tabular}




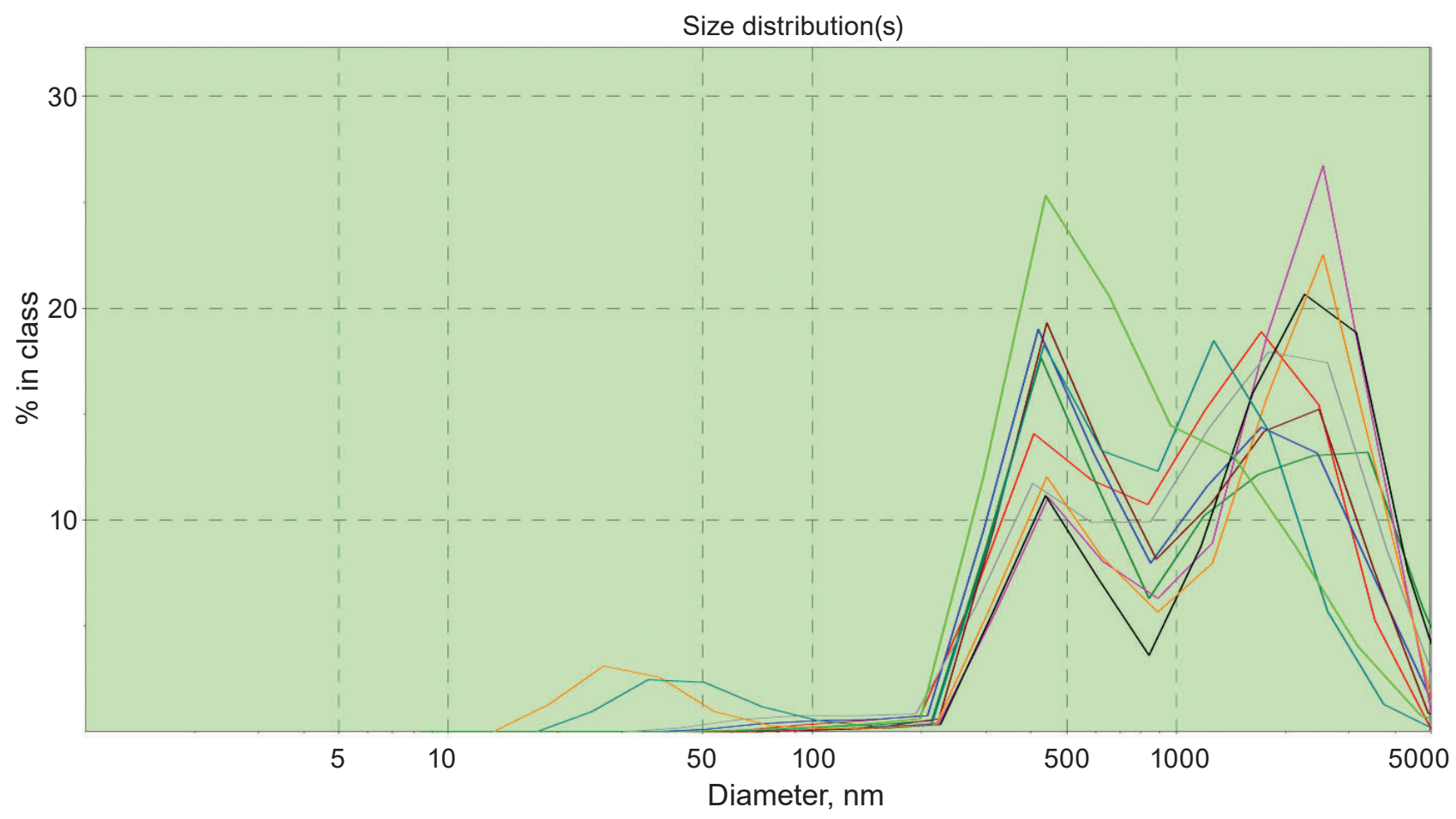

Fig. 1. The mitochondria size (volume) distribution in the presence of $5 \mu M$ cyclosporin as a stabilizing compound in sucrose medium

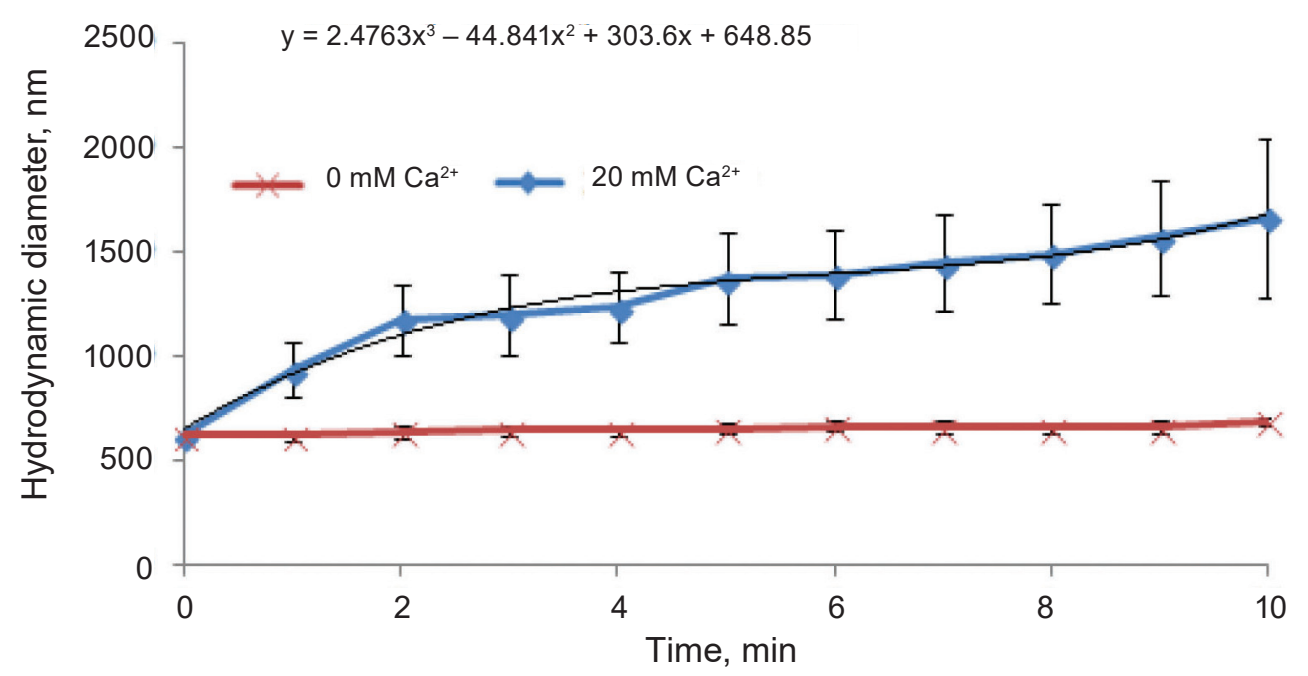

Fig. 2. Dynamics of mitochondria swelling induced by $20 \mathrm{mMCa}^{2+}$ in the sucrose medium; $M \pm m, n=5$. Black curve is approximation of the experimental data which are represented by blue curve. The equation derived from the experimental data is represented in Fig

of endoplasmic reticulum [20]. This feature is may be attributed to the non-specific modification of the subcellular membrane structures. Thus, we attributed increasing of mitochondria swelling upon the action of exogenous ultrahigh $\mathrm{Ca}$ concentrations to the increase in non-specific inner membrane perme- ability to this cation followed by an increase in its concentration in the matrix.

A high concentration of ionized calcium in the matrix along with low level of ATP led to the opening of PTP and the osmotic imbalance between the matrix and the extramitochondrial me- 


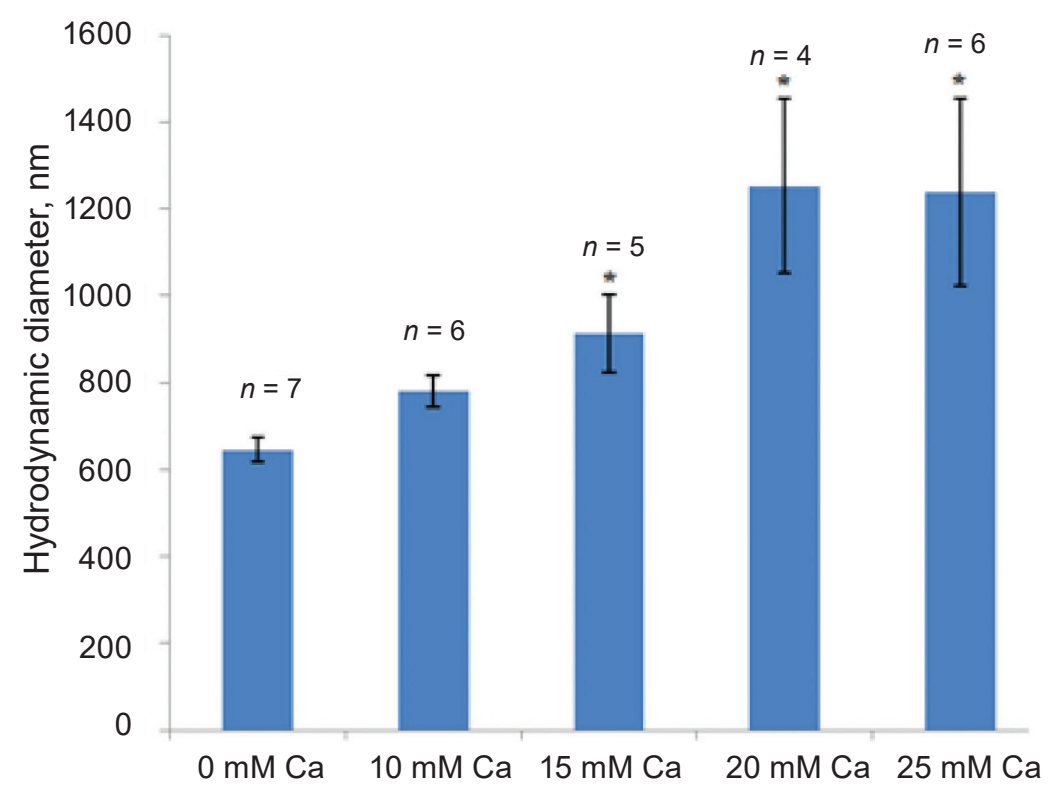

Fig. 3. Mitochondria swelling induced by exogenous $\mathrm{Ca}^{2+}$ at various concentrations in a sucrose medium; $M \pm m, *$ changes are statistically significant with respect to experiments with $0 \mathrm{mMCa}^{2+}(P<0.05)$

dium $[3,21]$. In the presence of Mg-ATP ${ }^{2-}$ complex ( $3 \mathrm{mM}$, equimolar amounts of $\mathrm{Mg}^{2+}$ and $\mathrm{ATP}^{4-}$ ) and under the experimental conditions the swelling was not observed. The latter indicates that the mitochondrial ATP-sensitive $\mathrm{K}^{+}$-channels, which are probably activated by $\mathrm{Ca}^{2+}$, were involved in the process of increasing of the matrix volume. It was also shown that $\mathrm{Mg}$ ions (1-3 $\mathrm{mM})$ themselves did not affect the mitochondria hydrodynamic diameter and did not protect organelles from swelling. However, $\mathrm{Ca}^{2+}$ induced increase in matrix volume was eliminated by $5 \mu \mathrm{M}$ cyclosporine (graph data are not shown) indicating a significant influence of cyclosporine sensitive PTP on the studied process. It was assumed that the mechanism of the $\mathrm{Ca}^{2+}$-dependent mitochondrial swelling includes both activation of ATP-sensitive $\mathrm{K}^{+}$-channels, and to a greater extent PTP involvement in disturbance of the osmotic balance.

The idea of a possible role of $\mathrm{K}^{+}$-permeability of inner mitochondrial membrane in the mechanisms for an increase in the organelles hydrodynamic diameter in hyper-calcium medium prompted us to study the influence of well-known blockers of $\mathrm{K}^{+}$channels on the swelling process. Due to the lack of sufficient concentration of $\mathrm{K}^{+}$(experiments with sucrose medium), a known non-selective inhibitor of $\mathrm{K}^{+}$-channels $1 \mathrm{mM}$ tetraethylammonium did not prevent swelling of organelles (Fig. 4, A). In the presence of physiological $\mathrm{K}^{+}$concentration $(132 \mathrm{mM})$, which is a prerequisite for the functional activity of mitochondrial $\mathrm{K}^{+}$-channels, an increase in the hydrodynamic diameter under the effect of $20 \mathrm{mM} \mathrm{Ca}^{2+}$ was more pronounced than in the sucrose medium (Fig. 4). This can be explained by the activation of $\mathrm{K}^{+}$transport through the channel structure into the matrix followed by mitochondria osmotic imbalance upon the action of ultra-high concentrations of $\mathrm{Ca}^{2+}$, which is probably able to activate certain subtypes of $\mathrm{K}^{+}$-channels. Significant inhibition of the organelles swelling (Fig. 4, B) was observed when using nonselective inhibitors of $\mathrm{K}^{+}$-channels such as tetraethylammonium and 4-aminopyridine (1 $\mathrm{mM})$, blocker of $\mathrm{Ca}^{2+}$-dependent $\mathrm{K}^{+}$-channels charybdotoxin $(20 \mathrm{nM})$ and blocker of ATP-sensitive $\mathrm{K}^{+}$-channels glibenclamide $(20 \mu \mathrm{M})$.

The obtained results indicate a possible involvement of various subtypes of $\mathrm{K}^{+}$-channels in the mitochondria swelling under the action of exogenous $\mathrm{Ca}^{2+}$ in ultrahigh concentrations. Probably, the $\mathrm{Ca}^{2+}$-overload along with inhibition of ATP generation lead to activation of mitochondria $\mathrm{Ca}^{2+}$ and ATP-sensitive $\mathrm{K}^{+}$-channels, and an increase in the concentration of $\mathrm{K}$ ions in the matrix, in turn, will contribute to the overall osmotic imbalance and organelles swelling.

Along with this, NO donor sodium nitroprusside $(0.1 \mu \mathrm{M})$ effectively inhibited the $\mathrm{Ca}^{2+}$ dependent swelling of myometrium mitochondria (graph data are not shown) that may be explained by the inhibitory effect of NO on PTP [22]. 
$A$

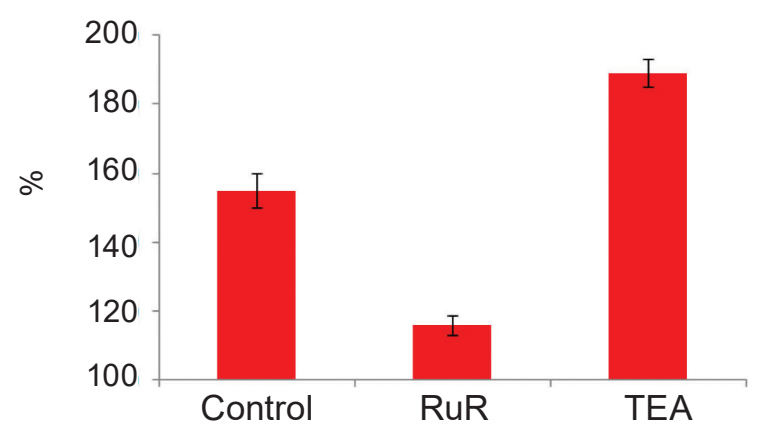

B

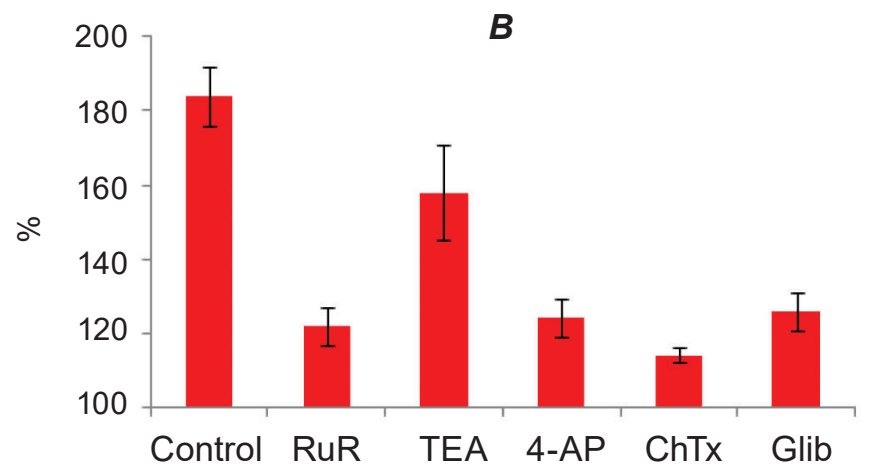

Fig. 4. Changes in hydrodynamic diameter of isolated mitochondria induced by ultra-high concentrations of $\mathrm{Ca}^{2+}(20 \mathrm{mM})$ in the presence of ruthenium red and $\mathrm{K}^{+}$channel inhibitors. $A$-sucrose medium, $B$-medium contains potassium chloride. Average value of mitochondria volume within 10 min of measurements before $\mathrm{Ca}^{2+}$ addition was taken as $100 \%$. Control - the swelling induced by Ca ions. The active compound concentrations: $10 \mu M$ RuR (ruthenium red), $1 \mathrm{mM}$ TEA (tetraethylammonium), $1 \mathrm{mM}$ 4-AP (4-aminopyridine), $20 \mathrm{nM}$ ChTx (charybdotoxin), $20 \mu M$ Glib (glibenclamide); $M \pm m, n=5$. All changes are statistically significant with respect to the control $(P \leq 0.05)$

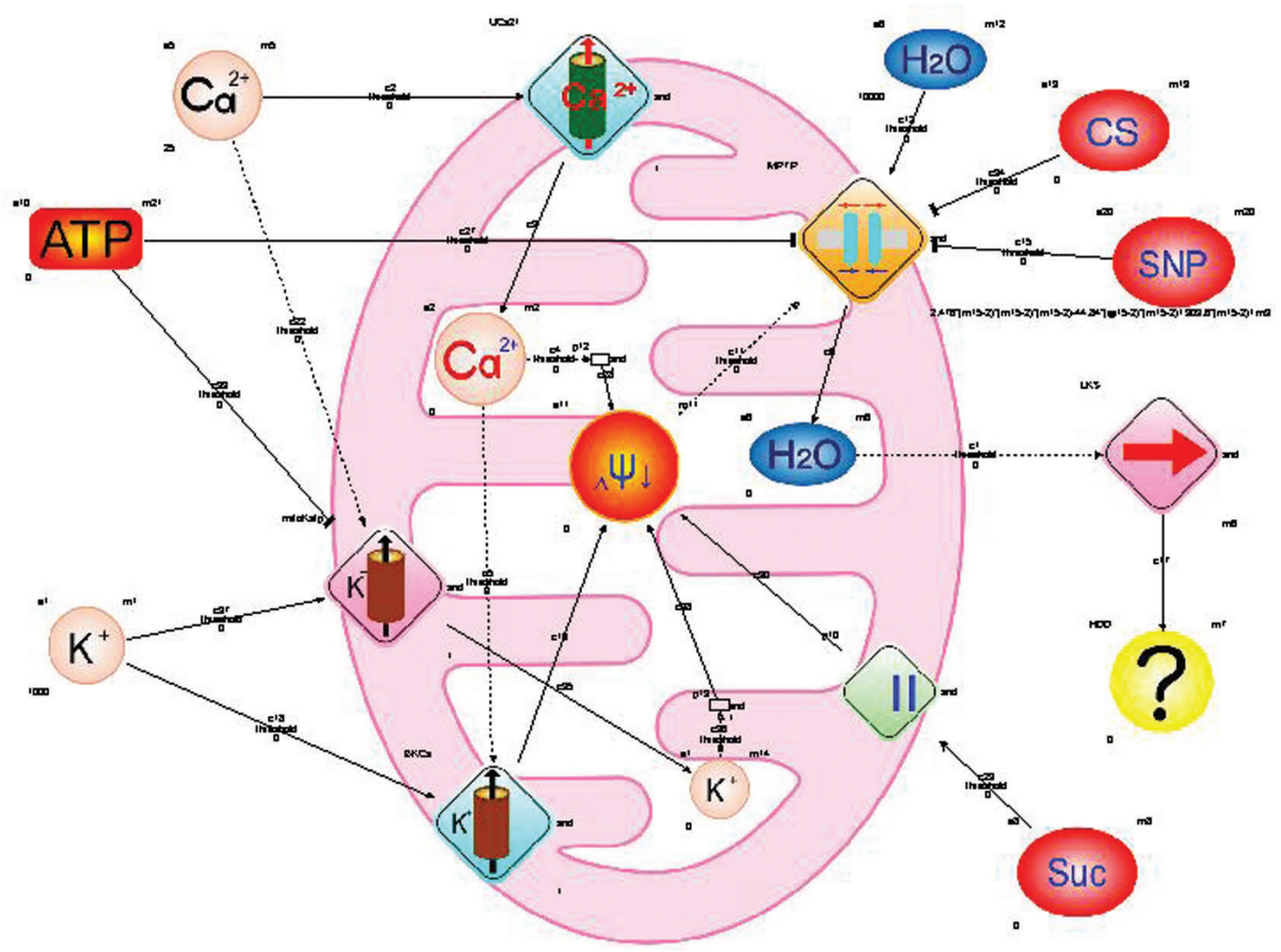

Fig. 5. The structure of the hybrid functional Petri nets, which simulates the Ca ${ }^{2+}$ effect on the changes of the hydrodynamic diameter of the myometrium mitochondria. Symbols on the scheme: CS-cyclosporin A, SNPsodium nitroprusside, Suc-sodium succinate, $\Delta \Psi$-electric potential of the inner mitochondrial membrane; $K^{+}$, $\mathrm{Ca}^{2+}$ (cation chemical symbols inscribed in a rhomb in the mitochondrial membrane) - corresponding channel structures of the inner mitochondrial membrane; II (inscribed in a rhomb in the mitochondrial membrane) - a second complex of electron transport chain; symbol-| |- inside a rhomb-cyclosporine-sensitive permeability transition pore; arrows: $\rightarrow$ activation of the process, $\top$ inhibition of the process 
Using the hybrid functional Petri nets we carried out modeling imitating the influence of $\mathrm{Ca}^{2+}$ (time and concentration patterns) on the value of the hydrodynamic diameter of myometrium mitochondria (Fig. 5).

The model takes into account the components of mitochondria incubation medium $\left(\mathrm{H}_{2} \mathrm{O}\right.$, ATP, succinate), activators of mitochondria swelling (Ca, K ions) and the corresponding inhibitors (cyclosporine, sodium nitroprusside). In particular, we considered the following facts: (1) - an increase in the permeability of the mitochondrial membrane to $\mathrm{Ca}$ ions under the influence of the hyper-calcium medium and the corresponding increase in the $\mathrm{Ca}$ ion concentration in the matrix; (2) - activation by $\mathrm{Ca}$ ions corresponding $\mathrm{Ca}^{2+}$-dependent $\mathrm{K}^{+}$-channel subtypes; (3) - inhibition by ATP corresponding ATP-sensitive $\mathrm{K}^{+}$-channel subtypes and PTP; (4) - the inner mitochondrial membrane depolarization upon intensification of $\mathrm{K}^{+}$and $\mathrm{Ca}^{2+}$ transport into matrix on the concentration gradient; (5) - opening PTP upon conditions of depolarization; (6) - blocking of PTP by cyclosporin A and sodium nitroprusside; (7) disorder of osmotic imbalance between the matrix and the extra-mitochondrial medium due to the PTP activation and followed by $\mathrm{H}_{2} \mathrm{O}$ transport into the matrix and increasing of organelle characteristic sizes; (8) - a role of succinate as a substrate acting at II complex level of electron transport chain. All of these processes are structurally indicated on the diagram (Fig. 5).

Through modeling we obtained mathematical equations, which formalize the process of mitochondria swelling in the medium with ultra-high concentrations of $\mathrm{Ca}^{2+}$. In particular, these equations can adequately describe the time characteristics of the process (Fig. 2).

According to Fig. 2 dynamics of the changes in the average values of mitochondria hydrodynamic diameter during swelling can be approximated by a polynomial of the third degree:

$$
\mathrm{D}=\mathrm{At}^{3}-\mathrm{Bt}^{2}+\mathrm{Ct}+\mathrm{D}_{0} \text {, }
$$

where: $\mathrm{A}=2.476 \mathrm{~nm} / \mathrm{min}^{3}, \mathrm{~B}=44.84 \mathrm{~nm} /$ $\min ^{2}, \mathrm{C}=303.6 \mathrm{~nm} / \mathrm{min}-$ model coefficients; $\mathrm{D}_{0}=650 \mathrm{~nm}-$ average hydrodynamic diameter of mitochondria in control.
Since the swelling was caused by osmotic unbalance between the matrix and the medium mostly due to the PTP activation, the permeability of PTP was the main model parameter. It is mathematically described as the time derivative of $\mathrm{D}$ :

$$
\mathrm{dD} / \mathrm{dt}=\mathrm{Et}^{2}-\mathrm{Ft}+\mathrm{C},
$$

where: $\mathrm{E}=7.428 \mathrm{~nm} / \mathrm{min}^{3}, \mathrm{~F}=89.68 \mathrm{~nm} / \mathrm{min}^{2}$, $\mathrm{C}=303.6 \mathrm{~nm} / \mathrm{min}-$ model coefficients; $\mathrm{t}-$ time, $\min$

We also modeled the concentration (as $\mathrm{Ca}^{2+}$ ) patterns of swelling based on the results presented in Fig. 3. The structural component of the model is similar to that shown in Fig. 5, but PTP permeability is described by the form:

$$
\mathrm{dD} / \mathrm{dC}_{\mathrm{m}}=\mathrm{HC}_{\mathrm{m}}{ }^{3}+\mathrm{JC}_{\mathrm{m}}{ }^{2}-\mathrm{KC}_{\mathrm{m}},
$$

where: $\mathrm{H}=-0.163 \mathrm{~nm} / \mathrm{mM}^{4}, \mathrm{~J}=6.68 \mathrm{~nm} / \mathrm{mM}^{3}$, $\mathrm{K}=41.08 \mathrm{~nm} / \mathrm{mM}^{2}-$ model coefficients; $\mathrm{C}_{\mathrm{m}}-\mathrm{Ca}^{2+}$ concentration, $\mathrm{mM}$.

Our model enables to predict the changes in the organelle hydrodynamic diameter in time that significantly optimizes the experimental procedures (time, consumption of reagents and laboratory animals), allows analyzing the dynamics of the process and comparing the results of modeling with actual observations under conditions of changes in the above parameters (composition of the incubation medium, the presence of activators/inhibitors).

Thus, in this work it has been demonstrated that ultrahigh concentrations of $\mathrm{Ca}^{2+}$ (over $10 \mathrm{mM}$ ) induced mitochondrial swelling, which did not occur in the presence of $\mathrm{Mg}-\mathrm{ATP}^{2-}$ and cyclosporin $\mathrm{A}$ in the medium. Inhibitory analysis showed that this effect is caused by increasing of non-specific mitochondrial membrane permeability to $\mathrm{Ca}$ ions, $\mathrm{Ca}^{2+}-$ overloaded matrix, activation of ATP- and $\mathrm{Ca}^{2+}$-sensitive $\mathrm{K}^{+}$channels as well as PTP.

The use of Petri nets enables to structurally represent these processes, to consider activating and inhibitory action of medium components and to quantitatively model the mitochondria swelling in the real experimental conditions.

\section{Acknowledgments}

We are deeply grateful to Member of NAS of Ukraine, Professor S. O. Kosterin for valuable advice during the discussion of the experimental results and the process of writing the manuscript. 


\section{ВИКОРИСТАННЯ МЕТОДОЛОГІї МЕРЕЖ ПЕТРІ ДЛЯ ІМІТАЦІЙНОГО МОДЕЛЮВАННЯ НАБУХАННЯ МІТОХОНДРІЙ}

\author{
Ю. В. Данилович, О. Ю. Чуніхін, \\ Г. В. Данилович, О. В. Коломієцьь \\ Інститут біохімії ім. О. В. Палладіна \\ НАН України, Київ; \\ e-mail: danylovych@biochem.kiev.ua
}

Iз використанням методу фотонної кореляційної спектроскопії, який дозволяє дослідити зміни гідродинамічного діаметра частинок у суспензії, показано, що $\mathrm{Ca}^{2+} \mathrm{y}$ надвисоких концентраціях (більше 10 мM) індукує набухання ізольованих мітохондрій. Збільшення гідродинамічного діаметра, зумовлене зростанням неспецифічної проникності мітохондріальних мембран до іонів $\mathrm{Ca}, \mathrm{Ca}^{2+}$ перевантаженням матриксу, активацією АТР- та $\mathrm{Ca}^{2+}$-чутливих $\mathrm{K}^{+}$-каналів, а також циклоспоринчутливої пори перехідної провідності. Для формалізації експериментальних даних та оцінки відповідності результатів теоретичним передбаченням була розроблена імітаційна модель із застосуванням методології гібридних функціональних мереж Петрі.

К л юч о в і с л о в а: мітохондрії, мережі Петрі, кальцій, пора перехідної провідності, фотонна кореляційна спектроскопія.

\section{ИСПОЛЬЗОВАНИЕ МЕТОДОЛОГИИ СЕТЕЙ ПЕТРИ ДЛЯ ИМИТАЦИОННОГО МОДЕЛИРОВАНИЯ НАБУХАНИЯ МИТОХОНДРИЙ}

\section{Ю. В. Данилович, А. Ю. Чунихин, А. В. Данилович, А. В. Коломиеи}

\section{Институт биохимии им. А. В. Палладина НАН Украины, Киев; e-mail: danylovych@biochem.kiev.ua}

С использованием метода фотонной корреляционной спектроскопии, который позволяет исследовать изменения гидродинамического диаметра частиц в суспензии, показано, что $\mathrm{Ca}^{2+}$ в сверхвысоких концентрациях (более 10 мМ) индуцирует набухание изолированных митохондрий. Увеличение гидродинамического диаметра обусловлено ростом неспецифической проницаемости митохондриальных мембран к ионам $\mathrm{Ca}, \mathrm{Ca}^{2+}$-перегрузкой матрикса, активацией $\mathrm{ATP}-$ и $\mathrm{Ca}^{2+}$-чувствительных $\mathrm{K}^{+}$-каналов, а также циклоспоринчувствительной поры переходной проводимости. Для формализации экспериментальних данных и оценки соответствия наших результатов теоретическому предсказанию была разработана иммитационная модель с использованием методологии гибридных функциональных сетей Петри.

К л ю че вы е с лов а: митохондрии, сети Петри, кальций, пора переходной проводимости, фотонная корреляционная спектроскопия.

\section{References}

1. Brocard JB, Rintoul GL, Reynolds IJ. New perspectives on mitochondrial morphology in cell function. Biol Cell. 2003; 95(5): 239-242.

2. Okamoto K, Shaw JM. Mitochondrial morphology and dynamics in yeast and multicellular eukaryotes. Annu Rev Genet. 2005; 39: 503-536.

3. Kaasik A, Safiulina D, Zharkovsky A, Veksler V. Regulation of mitochondrial matrix volume. Am J Physiol Cell Physiol. 2007; 292(1): C157-C163.

4. Nowikovsky K, Schweyen RJ, Bernardi P. Pathophysiology of mitochondrial volume homeostasis: potassium transport and permeability transition. Biochim Biophys Acta. 2009; 1787(5): 345-350.

5. Ponomarenko OV, Babich LH, Horchev VF, Kosterin SO. Studies of $\mathrm{Ca}^{2+}$-dependent smooth muscle mitochondria swelling using flow cytometry and spermine effects on this process. Ukr Biokhim Zhurn. 2006; 78(6): 38-45.(In Ukrainian).

6. Belosludtsev KN, Belosludtseva NV, Dubinin MV, Gudkov SV, Pen'kov NV, Samartsev VN. The influence of spermine on $\mathrm{Ca}(2+)$-dependent permeability transition in mitochondria and liposomes induced by palmitic and $\alpha, \Omega$-hexadecanedioic acids. Biofizika. 2014; 59(5): 895-901. (In Russian).

7. Merkus HG. Particle size measurements. Fundamentals, practice, quality. Springer, 2009. $533 \mathrm{p}$.

8. Koch I, Reisig W, Schreiber F. (eds.) Modeling in Systems Biology. The Petri Net Approach. Springer, 2011. 388 p. 
9. Wingender E. (ed.) Biological Petri Nets. IOSPress, 2011. 314 p.

10. Ritter U, Prylutskyy YuI, Evstigneev MP, Davidenko NA, Cherepanov VV, Senenko AI, Marchenko OA, Naumovets AG. Structural features of highly stable reproducible $\mathrm{C}_{60}$ fullerene aqueous colloid solution probed by various techniques. Fullerenes, Nanotubes, Carbon Nanostruct. 2015; 23(6): 530-534.

11. Kandaurova NV, Chunikhin OIu, Babich LG, Shlykov SG, Kosterin SO. Modulators of transmembrane calcium exchange in myometrium mitochondria change their hydrodynamic diameter. Ukr Biokhim Zhurn. 2010; 82(6): 52-57. (In Ukrainian).

12. Kosterin SA, Bratkova NF, Kurskiy MD. The role of sarcolemma and mitochondria in calciumdependent control of myometrium relaxation. Biokhimiia. 1985; 50(8): 1350-1361. (In Russian).

13. Bradford MM. A rapid and sensitive method for the quantitation of microgram quantities of protein utilizing the principle of protein-dye binding. Anal Biochem. 1976; 72: 248-254.

14. Nagasaki M. et al. Foundations of Systems Biology. Using Cell Illustrator and Pathway Databases. Springer, 2009. 166 p.

15. Ryu SY, Beutner G, Dirksen RT, Kinnally KW, Sheu SS. Mitochondrial ryanodine receptors and other mitochondrial $\mathrm{Ca}^{2+}$ permeable channels. FEBS Lett. 2010; 584(10): 1948-1955.

16. Babich LH. Membrane mechanisms of regulating $\mathrm{Ca}$ ion concentration in smooth muscle cells. Ukr Biokhim Zhurn. 1999; 71(5): 10-22. (In Ukrainian).
17. Chan L, Wong YC. Cytochemical localisation and characterisation of proteoglycans (glycosaminoglycans) in the epithelial-stromal interface of the seminal vesicle of the guinea pig. J Anat. 1992; 180(Pt 1): 41-56.

18. Wieraszko A. Evidence that ruthenium red disturbs the synaptic transmission in the rat hippocampal slices through interacting with sialic acid residues. Brain Res. 1986; 378(1): 120126.

19. Santo-Domingo J, Demaurex N. Calcium uptake mechanisms of mitochondria. Biochim Biophys Acta. 2010; 1797(6-7): 907-912.

20. Herrmann-Frank A, Darling E, Meissner G. Functional characterization of the $\mathrm{Ca}(2+)$-gated $\mathrm{Ca}^{2+}$ release channel of vascular smooth muscle sarcoplasmic reticulum. Pflugers Arch. 1991; 418(4): 353-359.

21. Zaobornyj T, Ghafourifar P. Strategic localization of heart mitochondrial NOS: a review of the evidence. Am J Physiol Heart Circ Physiol. 2012; 303(11): H1283-H1293.

22. Brookes PS, Salinas EP, Darley-Usmar K, Eiserich JP, Freeman BA, Darley-Usmar VM, Anderson PG. Concentration-dependent effects of nitric oxide on mitochondrial permeability transition and cytochrome $c$ release. $J$ Biol Chem. 2000; 275(27): 20474-20479.

Received 21.06.2016 